bring joy to the hearts of bird watchers. Here is a golden opportunity to learn more about the poorly understood habit of anting in birds. Do birds ant because the substances they use pleasantly stimulate the skin and, in some instances, act as a counter-irritant, or does the habit have a more utilitarian purpose?

I am grateful to Jean Bancroft for keeping me informed about recent outbreaks of grackles anting with marigold blossoms.

1 CHISHOLM, A.H. 1959 The history of anting. Emu 59:101-130
2 DARWIN, C. 1874 Flowers of the primrose destroyed by birds. Nature 10:24

3 DENNIS, J.V. 1981 Beyond the bird feeder. Alfred A. Knopf, New York

${ }^{4}$ NERO, R.W. and D.R.M. HATCH 1984 Common grackles anting with marigold flowers. Blue Jay $42(4): 212-214$

5 NICE, M. and J. TER PELKWYK 1940 'Anting' by the Song Sparrow. Auk 57:520-522.

${ }^{6}$ RODALE, J.I. (Ed.) 1959 Encyclopedia of organic gardening. Emmaus, Pa.

EDITOR'S NOTE: An article on anting "Anting antics," by Eloise F. Potter, just appeared in the summer issue of The Living Bird 4(3):12-15.

\title{
FIRST SAGE THRASHER SIGHTING MANITOBA
}

ANDREW HORN and PETER CHRISTIE, Department of Zoology, Univesity of Toronto, Toronto, Ontario. M5S 1A1

The senior author has been studying Western Meadowlarks along the Assiniboine Diversion near its mouth at Lake Manitoba. On 10 June 1984, at $0530 \mathrm{~h}$ the authors were watching a meadowlark near the Peters' farmhouse about $10 \mathrm{~km}$ south of the lake, when an unusual bird was noted beneath the meadowlark.

At first glance, at was apparent that it was a rare bird. It was three-quarters the size of the meadowlark and slim, with upperparts and legs the color of dry modeling clay. The breast had many narrow streaks of that color. Otherwise, the breast was a dirty, pale, brownish-white. The tail was distinctly darker than the back, with white tips to the outer feathers that became obvious when the bird flew. No obvious wingbars were seen. The most striking features were the yellow eye, moustaches bordering the throat, a short, slender and slightly decurved bill, pale toward the base, and the breast streaking.

After almost 3 minutes of observations the bird was identified as a Sage Thrasher. Having observed Crissal, Brown and California Thrashers in the wild, Horn was struck by this species' small size and short bill. The thrasher ran and paused in typical thrush fashion, but with the more horizontal posture and protruded head of a thrasher. 
The bird was watched for about $30 \mathrm{~min}$. from 15 to $50 \mathrm{~m}$ away, with $7 \times 50$ binoculars and a $20 \times 100$ spotting scope. Spencer Sealy of the University of Manitoba was present part of this time and agreed with the identification, drawing on previous experience with nesting Sage Thrashers in the Okanagan Valley, B.C. He notified birders in the Winnipeg area, so that by 12 June, when the bird was last seen, it had been observed by at least eight parties and had been photographed.

Typical habitat around the Peters' farmhouse consisted of cultivated and hay fields. The bird was seen along a gravel road by the farmhouse, on some bare ground among planted conifer seedlings, and in tall cultivated shrubs around the house.

Although the Sage Thrasher does nest in Saskatchewan and North Dakota, ${ }^{1}$ this is the first sighting for Manitoba.

\section{Acknowledgements}

We thank Spencer Sealey for helping to confirm the sighting. Ian Jones commented on a draft of the manuscript.

1 GODFREY, W.E. 1966 The birds of Canada. National Museums of Canada. Bull. 203. 428 pp.

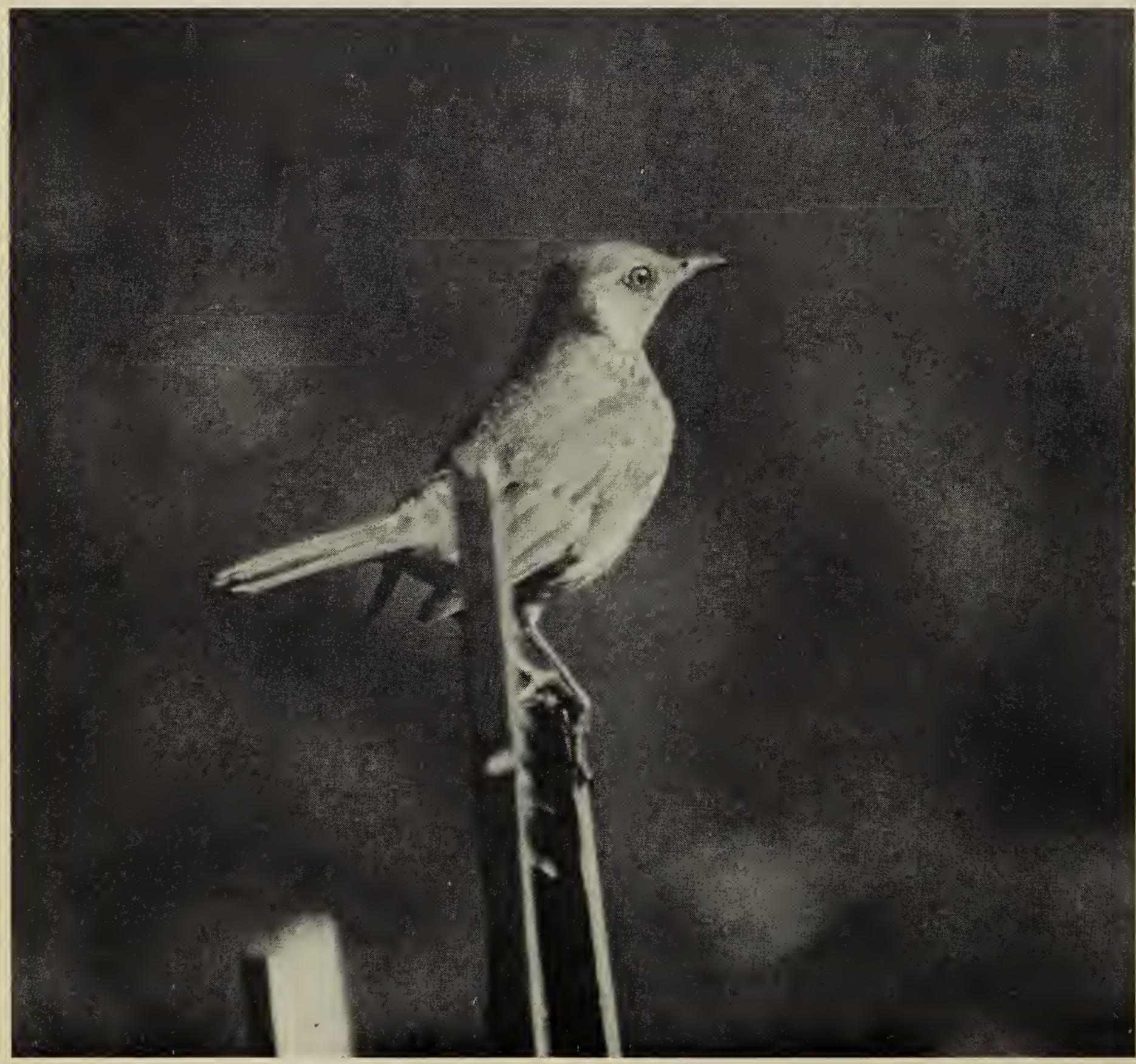

